\title{
The Eurozone debt crisis: the options now
}

\author{
Lee C. Buchheit and G. Mitu Gulati*
}

\section{Key points}

- The Eurozone debt crisis is entering its third year. The original objective of the official sector's response to the crisis-containment-has failed. All the countries of peripheral Europe are now in play; three of them (Greece, Ireland and Portugal) operate under full official sector bailout programmes.

- The prospect of the crisis engulfing the larger peripheral countries, Spain and Italy, has sparked a new round of official sector containment measures. These will involve active intervention by official sector players such as the European Central Bank in order to preserve market access for the affected countries.

- This article surveys the options now facing the sovereign debtors and their official sector sponsors. It concludes that there are no painless or riskless options. In the end, the question may come down to this - to what extent will the official sector sponsors of peripheral Europe be prepared to take on their own shoulders (and off of the shoulders of private sector lenders) a significant portion of the debt stocks of these countries during this period of fiscal adjustment?

The Eurozone debt crisis will soon enter its third year; 3 years marked by wild gyrations in both policy and practice. The principal objective to date has been, to use a cold war term, containment. But little has in fact been contained. Greece-the epicentre of the crisis-remains exceptionally fragile. Portugal and Ireland are wards of their official sector lenders (the EU and the IMF). Spain and Italy must watch their bond yields each morning with palpable anxiety. And some churlish commentators even speak, in hushed and conspiratorial tones, about the possible infection of the 'core' of Europe.

\section{How we got here}

When the crisis first overwhelmed Greece in the spring of 2010, the Hellenic Republic had in excess of $€ 300$ billion of debt outstanding, virtually all of it in the hands of private sector creditors. In crafting a bailout package for the country in May 2010, Greece's official sector supporters faced an obvious choice-would they lend Greece the money required to repay its maturing debts in full and on time, or would Greece be told to restructure those debts so as to shift the maturing amounts out of the adjustment programme period. The official sector chose the former option; a gross bailout in the amount of $€ 110$ billion that included a large allocation to pay maturing Greek debts. 
The historical precedents pointed in the other direction. During the Latin American debt crisis of the 1980s and early 1990s, ${ }^{1}$ the IMF's prescription for debtor countries was stultifyingly predictable_-raise revenues (tax), reduce expenditures (cut) and stretch out the maturities of existing obligations (restructure). The official sector at that time was asked, but steadfastly refused, either to guarantee the debts of the more than 20 countries that were engulfed in the crisis or to lend those countries the money to repay their existing debts in full and on time. In effect, this policy grabbed the existing private sector lenders by the nose and forced them to extend their loans into a future that held 'either' a return to normal debt servicing 'or' a more severe form of debt restructuring involving a haircut to principal and/or interest. With the benefit of hindsight, of course, we now know that Nicholas Brady, the successor US Treasury Secretary, waited in that misty future with his eponymous Brady Bonds. Creditor haircuts would eventually come at the hands of Mr Brady, but only 8 years after the crisis first started.

Why should the official sector lenders to Greece in the spring of 2010 have chosen such a radically different course, effectively using taxpayer money to repay existing lenders at par? There were three motivations at the time:

- Fear of contagion: if holders of Greek bonds were forced to restructure, might not the fear of similar treatment infect the holders of the bonds of Ireland, Portugal, Spain, Italy and perhaps others?

- Balance sheet damage: the lenders to Greece in the spring of 2010 were predominately French and German banks. A restructuring of the Greek portfolios of those institutions would inevitably have disagreeable consequences for the balance sheets of those creditors. So bailing out Greece was simply an indirect (and more politically palatable) way of bailing out overexposed financial institutions in northern Europe.

- Reputation of the euro: a few people (mostly at the senior levels of the European Central Bank) worried that a restructuring of any Eurozone sovereign debt instrument would indelibly tarnish the reputation of the euro itself. This was a fate, they argued, to be avoided at all costs, even if it meant a public sector assumption of Greek liabilities.

So starting in May 2010, Greece began drawing down on its official sector loans, partly to cover its budget deficits, but mostly to repay its bondholders at par. The liabilities thus inexorably began to migrate out of the hands of the folks who had lent the money and taken the commercial risk (the bondholders) and into the hands of Greece's official (taxpayer funded) sponsors. It was a policy that lasted for 14 months, until the summer of 2011.

It seems belatedly to have dawned on the official sector players that they were gradually displacing their private sector counterparts as the principal lenders to Greece. If a debt restructuring was to become unavoidable, and the word 'unavoidable' was by the summer of 2011 distinctly in the air, that restructuring might have to fall on the official sector lenders, with all the predictable political consequences.

Starting in the summer of 2011, the official sector therefore careened from its prior policy of insisting that every creditor of Greece be paid in full to the antipodal extreme of demanding that all remaining private sector bondholders 'voluntarily' agree to

1 The Latin American debt crisis is something of a misnomer. It also affected countries in Asia, Africa and Eastern Europe. The crisis is generally thought to have started in August 1982 with the announcement of a moratorium on Mexican debt, and ended in the mid-1990s with the last of the Brady restructurings. 
restructure their claims against the country. By that point, of course, the corpus of Greek bonds remaining in private hands had shrunk to the point that achieving the official sector's debt relief target required a writeoff of 53.5 percent of the nominal amount of the bondholders' claims. Greece closed just this transaction in March of this year, erasing approximately $€ 100$ billion from its stock of debt in the hands of private sector creditors.

\section{The diagnosis}

The original objective of containing the Eurozone debt crisis has failed. Exactly why it failed depends on your point of view. Some would argue that the measures adopted to ensure containment were inept, inconsistent and insufficient. The more charitably disposed may say that the underlying economic problems of the peripheral countries were so intractable that nothing short of a decision to monetize every debt instrument south of the Rhine could have successfully stopped the rot. Ireland and Portugal were the next to go; Cyprus, Italy and Spain now twitch nervously in the crosshairs.

The options facing the Eurozone at this stage are a function of how the current problem is being diagnosed by the official sector. In a word, the view of the official sector is that we are confronting a temporal problem. Spain and Italy have each embarked on an aggressive programme of voluntary fiscal adjustment. All that is needed, the argument goes, is time. Time to let that fiscal adjustment produce its desired effect. Above all, time for the markets to appreciate that the adjustment programmes are irreversible and to reward the countries with lower interest rates on their new debt issuances. If we could only fast forward for a few years, this view holds, the entire problem would evaporate like a mist on a chilly hillside in the springtime. The only question is how to bridge this gapmeasured in months or at most a few years-between the announcement of fiscal adjustment and the market's willingness to reward that adjustment with lower risk premia.

\section{The options}

There are five, but probably only five, options for dealing with countries like Spain and Italy. These are ranked below in descending order of their attractiveness to the debtor country.

\section{Option One: jolly the markets}

The preferred option for the debtor country, and the stage we are currently in with Spain and Italy, is to jolly the markets into an act of faith, hope and charity. Politicians from debtor countries and elsewhere attempt to persuade the markets that the voluntary (to be contrasted with IMF-prescribed) fiscal adjustment programmes adopted by these countries are indeed irreversible and will inevitably restore the countries to a sound financial footing. Accordingly, they argue, the markets should have faith in this inevitability and should immediately moderate their interest rate expectations. 


\section{Option Two: massage the yields}

If Option One fails and the market cannot be persuaded voluntarily to accept low coupons (and we are surely on the cusp of that failure for Spain at least), the second option involves active official sector intervention in the primary or the secondary markets in order to suppress the yields on a debtor country's paper and thereby permit continued access to market borrowings at tolerable coupon levels. This intervention can take one of two forms. An official sector player such as the ECB or ESM could purchase bonds in the primary (ESM) or secondary (ECB or ESM) markets. This added demand should put downward pressure on yields. More on this below. Alternatively, the official sector could offer some form of partial credit support for new issuances by the debtor country-a partial guarantee, insurance policy or 'put' arrangement. This technique bleeds an element of AAA credit risk into each new bond and thus allows it to be sold with a lower coupon.

Admittedly, the track record for official sector intervention to massage yields on sovereign bonds is not good. In the early days of the European debt crisis, the ECB intervened in the secondary markets to buy Greek, Irish and Portuguese bonds. The effort failed in each case to preserve market access for more than a few weeks or months.

If Options One and Two both fail, the country loses market access (as happened in Greece, Ireland and Portugal).

\section{Option Three: full bailout}

If it is unable to refinance maturing amounts through market borrowings at bearable interest rates, the debtor country will prefer a full official sector bailout; that is, a bailout package which includes an amount sufficient to cover projected budget deficits and to repay all maturing obligations during the adjustment programme period. ${ }^{2} \mathrm{~A}$ full bailout allows the debtor to avoid the opprobrious label 'defaulter'. A cynical politician in the debtor country may even conclude that if a debt restructuring becomes necessary down the road, such an operation would be far easier with the liabilities concentrated in the hands of a few official sector lenders rather than thousands of private sector bondholders.

\section{Option Four: reprofiling}

Were the official sector to balk at paying out existing creditors at par (the now widely recognized error of the first Greek bailout), some form of debt restructuring becomes inevitable. The mildest debt restructuring technique that will accomplish the official sector's objective of moving maturities out of the programme period is known as a debt reprofiling. This technique, used successfully by Uruguay in its restructuring in 2003, has the merit of simplicity. The maturity dates of all items of outstanding debt (except perhaps for short-term Treasury bills) are shifted out by a fixed number of years-3, 5 or 7 years, for example. In a Uruguay-style reprofiling, no haircut is applied to the principal

2 Post-ESM, this could be accomplished by having the ESM buy new debt issuances directly in the primary market. This would at least preserve, in a Potemkin Village setting to be sure, the appearance of normal market operations. 
of the debt and the interest rate applicable to the extension period is the original coupon rate on each of the affected instruments.

A reprofiling offers these advantages:

- Local politicians can claim that investors will be paid back every euro they lent together with interest calculated at the original rate. The repayment of principal will merely be delayed a bit.

- A reprofiling moves maturities out of the programme period and obviates the need for the official sector to fund those maturities; this is its principal charm in the eyes of the official sector.

- The net present value loss to investors resulting from a reprofiling is muted. It will depend, of course, on the length of the extension period. In Uruguay's case (a 5-year extension), the NPV loss was about 19 per cent.

- If the debtor country cannot return effortlessly to normal market borrowing when the period of the extension ends, the ensuing debt restructuring will bite the private sector lenders, not taxpayers.

\section{Option Five: full (Greek-style) restructuring}

The final option is a full restructuring of the debt stock combining both a maturity extension and principal/interest haircuts. This is where Greece wound up in the spring of 2012.

\section{Can market access be preserved?}

The battle for Option One as it relates to Spain (jolly the markets into continuing to lend) is quickly being lost. The battle for Option Two (massage the yields) is about to begin.

On 6 September 2012, the European Central Bank announced its willingness to commence a programme - the Outright Monetary Transactions (OMT) programme-of buying short-term (1-3 years) bonds of Eurozone countries in the secondary market, in unlimited amounts, ${ }^{3}$ in order to suppress the yields on those instruments. The objective of the OMT programme is to allow afflicted countries to continue to issue paper in the primary market at tolerably low interest rates. OMT purchases of the bonds of a country would be expressly conditioned, however, on that country's acceptance of a formal, IMF-approved and monitored adjustment programme; 'voluntary' fiscal adjustment will not be sufficient. The ECB also announced that in the event of a future debt restructuring of bonds acquired in the OMT programme, the ECB will accept the same treatment as private creditors. ${ }^{4}$ Aggregate OMT purchases will be reported weekly with country-by-country breakdowns published each month. The ECB has said that it expects to publish the market value of its OMT positions.

3 The sentence in ECB's 6 September 2012 Press Release reads: 'No ex ante quantitative limits are set on the size of Outright Monetary Transactions.'

4 What this assurance will mean in practice is not yet clear. On 4 October 2012, ECB President Draghi was asked why the ECB would not roll over (that is, restructure) its holdings of Greek government bonds. His answer (as reported by Reuters):

[Rolling over] would qualify as monetary financing. We have said several times that any voluntary restructuring of our holdings would be equivalent - would be monetary financing.

Monetary financing of a Member State is impermissible under the ECB's charter. How this statement can be squared with the 6 September promise to accept equal treatment with private creditors in the event of a restructuring of OMT-acquired bonds remains to be seen. See link: http://www.reuters.com/article/2012/10/04/ecb-rates-idUSECBNEWS20121004. 
No one doubts ECB's financial capacity to run the OMT programme. After all, ECB owns the proverbial printing press. It is political rope that may be in shorter supply. If indeed the ECB is forced to open the OMT throttle for Spain and/or Italy, these risks loom:

- The market will obviously realize that its own assessment of the appropriate risk/reward calculus (reflected in the coupon the market demands on a new bond) has been skewed by the presence of an official sector 'deus ex machina' ${ }^{5}$ in the process. Investors will presumably continue to buy those bonds at that officially induced interest rate only if they believe that either (i) they effectively are being given a put of the instruments to the ECB or (ii) in the event of a future restructuring the ECB, as the largest holder of the bonds and now publicly committed to accept 'pari passu' treatment, will use its considerable leverage to ensure that short-dated bonds are exempted from (or treated very leniently in) the restructuring.

- Nonetheless, the markets may mercilessly test the ECB's willingness to persist in buying unlimited quantities of peripheral sovereign bonds. And every time a prominent politician in Germany or elsewhere, perhaps goaded by an ECB report of an eye-watering mark-to-market loss on OMT-acquired bonds, rails against the OMT programme, the shorts will be emboldened. ${ }^{6}$ They will constantly be measuring the amount of political rope left in the ECB's coil. Once the ECB commences buying, it must be prepared to continue doing so until the earlier to occur of a capitulation by the shorts or a general market acceptance that the crisis has abated in the target country.

- The OMT programme will apparently restrict its buying to the short end of the yield curve (1-3 years). Every atom of the political flesh in the debtor country will therefore want to concentrate primary market borrowings in this sweet spot where the yields benefit from official sector intervention. Why borrow for 10 years at 9 per cent when one can borrow for 2 years at 3 per cent? Unless restricted by the terms of the IMF-prescribed adjustment programme, however, this tendency to borrow short will very quickly produce an alarming debt profile, one characterized by a Himalayan spike in the early years. The optical impression that such a spike will leave on the retinas of prospective investors may itself become an obstacle to renewed market access.

- What happens if austerity fatigue forces the politicians in the debtor country to fall out of the fiscal adjustment bed at a time when the ECB owns a sizeable chunk of OMT-acquired bonds? Experience tells us that public resentment of austerity measures tends to intensify when the aggrieved citizens perceive the author of their misery to be an organization such as the IMF rather than their own elected representatives. The danger here is that the ECB, and more generally the EU, could become a hostage to its own policies. Rather than abruptly suspend further OMT purchases to a non-complying country, with the predictable consequence of an immediate spike in yields and massive mark-to-market losses in the OMT portfolio, the Europeans may feel that they have little choice but to accede to whatever relaxation of the adjustment programme is demanded by the debtor country. So much for OMT conditionality.

The lesson? Before agreeing to play a 'deus ex machina' role, an actor is well advised to ensure that the crane will be adequate to get the god all the way to the stage floor.

\section{Assessing the options}

Again, the official diagnosis of this situation is that it is a footrace; can market access at tolerable interest rate levels be preserved long enough for the benignant effect of fiscal austerity programmes to become visible to the market? If interest rates rise to an unsustainable level before the adjustment programmes have had time to do their good work, the race is lost.

5 'God from a machine'. In Greek drama, an otherwise insoluble problem could be solved by lowering a god onto the stage by means of a crane-like device at the appropriate point in the play.

6 Naked shorting of sovereign bonds in Europe will theoretically be banned starting in November of this year. History teaches, however, that an itch to short will not long go unscratched in one fashion or another. 
Option One (cajole the markets into an act of faith, hope and charity) appears to be ending; perhaps it never really had much of a chance.

Option Two (massage the yields) is about to begin. The OMT programme may work but its fate will turn crucially on three factors that are difficult to handicap. How relentlessly will the markets test the ECB's resolve to continue buying peripheral bonds in unlimited quantities? Second, how successful will the ECB be in mollifying the unhappiness of its largest shareholder with the very idea of buying bonds in the secondary market for this purpose? Third, will the economic recovery of the affected countries (and their planned return to normal market borrowing) be delayed by forces beyond their control, a further slowdown in global economic growth for example. This could require the 'deus ex machina' to stay on the stage longer than anyone anticipated.

For two reasons, Option Three (full bailout), if it is tried at all, may not last long. First, the memory of the ill-fated May 2010 Greek bailout is still fresh in the minds of the official sector. Will taxpayer money again be used to repay, in full and on time, private sector creditors, particularly when OSI (official sector involvement, $\mathrm{a} / \mathrm{k} / \mathrm{a}$ restructuring of official sector debt) is in the offing? Second, are there sufficient resources in the European bailout mechanisms to repay all of the maturing debt of the countries now in play over even the next 15 months?

Option Five (a Greek-style restructuring) seems unlikely. In Spain and Italy, most of the foreign investors have already exited and been replaced by local financial institutions-banks, insurance companies and pension funds. A massive haircut to the debt stocks of either of these countries will therefore only decapitate the domestic financial systems. The money saved in debt service will have to be used to recapitalize those institutions.

As Sherlock Holmes might have said, exclude the impossible and whatever is left, however improbable, must be true. That logic leaves Option Four, a debt reprofiling designed to shift maturities out of the adjustment programme period while inflicting the least possible NPV loss on the debtholders. As the months roll sweetly on, however, a Uruguay-style debt reprofiling becomes less and less attractive. Uruguay had the luxury of extending its bond issues at their original coupon levels because those bonds had been issued at a time when Uruguay was investment grade. So the reprofiling meant an extension of low-coupon debt.

European peripherals were in a similar situation at the start of this crisis; their bonds had been issued during the sunny years when the market failed to register any significant credit distinctions among Eurozone members. The coupons on those bonds, even for Greece, were therefore only marginally higher than equivalent-maturity German bonds.

Once the illusion of uniform creditworthiness within the Eurozone was blasted by the events in Greece in early 2010, the coupons on new issuances of debt by European peripherals increased significantly. A Uruguay-style extension of the entirety of the debt stock of one of these countries today will therefore not be as attractive as it would have been 2 years ago, and it grows less attractive as each month passes and maturing debt 
has to be rolled over at interest rates higher than those applicable to the original issuances.

Let's be clear: a debt restructuring, even a mild one like a reprofiling operation, is a last resort alternative for most members of the official sector. They may eventually come to it, as they eventually came to it in Greece, but only if all other alternatives show themselves to be financially or politically untenable. Even now, the official sector takes every opportunity to describe the Greek restructuring as 'unique and exceptional'.

Notwithstanding this revulsion to a debt restructuring, if one becomes unavoidable the process will be facilitated - as it was in Greece-by the high percentage of local law instruments in the affected debt stock. Moreover, the concentration of the paper in the hands of local investors, while it may rule out the more savage debt restructuring techniques, should at least give the sovereign a malleable creditor universe. Local institutions are susceptible to forms of governmental persuasion to which foreigners are immune. 